\title{
Evaluation of Soil Health in Short Term Organic Vs Conventional Practices during Paddy Cultivation
}

\author{
Vandana Jaggi ${ }^{1 *}$, Samiksha Joshi ${ }^{1}$, Hemant Dasila ${ }^{1}$, \\ B.S. Mahapatra ${ }^{2}$ and Manvika Sahgal ${ }^{1}$ \\ ${ }^{1}$ Department of Microbiology, ${ }^{2}$ Department of Agronomy, G. B. Pant University of Agriculture \\ and Technology, Pantnagar-263 145, Uttarakhand, India \\ *Corresponding author
}

\begin{abstract}
A B S T R A C T
Soil health indicators such as soil physico-chemical properties, total bacterial count, microbial enzyme activities were monitored at different crop growth stages (such as before

Keywords

Paddy cultivation, Organic amendment, Pusa Basmati 1, Soil health indicators, Enzyme activities

Article Info

Accepted: 07 March 2018 Available Online: 10 April 2018 ploughing, after transplantation (0 DAT), max tillering (45 DAT), flowering (60 DAT) and maturity (90 DAT) of rice variety Pusa Basmati 1 . The treatment comprises green manure Sesbania rostrata and inorganic fertilizers for organic and conventional respectively. Moreover, field was cultivated with rice variety Pusa Basmati I. Total bacterial count; microbial enzyme activities (i.e Dehydrogenase, Fluorescein diacetate and Urease) and soil organic $\mathrm{C}$ and $\mathrm{N}$ significantly enhanced with crop growth and were maximum at maturity 90 DAT. Conversely, inorganic fertilizers did not affect soil $\mathrm{C}$ and N. However soil pH and alkaline phosphatase (AP) enhanced with crop growth. The calculated crop yields for organic and conventional treatments were 39.14 and $41.81 \mathrm{q} / \mathrm{ha}^{-1}$ respectively. Probable reason behind low yield in organic amendment could be short duration experiment study. Moreover, rice variety Pusa Basmati I is responsive for inorganic fertilizer. Result of this study suggest that green manure is a good source of organic nutrient to maintain soil health and crop yield but field require at least 3-5 years to under organic farming practices to give desirable results.
\end{abstract}

\section{Introduction}

Demand for organic farming is emerging owing to ill effects of agro-chemicals on environment as well as human health. It is a unique production management system, which enhances and propagates agro system health including biodiversity, biological cycles and soil biological activity. Conventional agricultural practices like excess use of chemical fertilizers and pesticides negatively affect the soil health. Soil health is defined as continued capacity of a specific soil type to sustain plant productivity and maintain favourable environment to sustain habitation and human health. Hence, soil health is key to achieving agricultural sustainability. Organic farming is an eco-friendly practice, it involves practicing crop rotation, using biofertilizers and pesticides (Kontopoulou et al., 2015) to enhance the product quality and promote environmental safety. Currently organic mode 
of agriculture is practiced in 162 countries world over, accounting for $0.86 \%$ of total agricultural land. In India area under organic farming increased from 0.46 million $\mathrm{ha}^{-1}$ in 2009-10 to 0.72 million $\mathrm{ha}^{-1}$ in 2013-2014 (DAC \& FW, 2016; Lernoud and Willer, 2016), which accounts for $0.4 \%$ of the total land under agriculture. Problems like soil erosion, decreased soil productivity due to frequent use of inorganic fertilizers divert the farmers towards organic farming practices. In India Oryza sativa is a staple crop next to wheat. Globally rice is cultivated on an area of about 155.62 million ha $^{-1}$ with production of 461 million ton and productivity of 4.09 ton $/ \mathrm{ha}^{-1}$. India ranks first in world with respect of area under rice cultivation (44.50 million ha) and second in production 102.75 million tonne, only after China, but the productivity is very low only 2.20 ton $\mathrm{ha}^{-1}$ (Anonymous, 2012).

Soil organic matter (SOM) plays an important role in enhancing soil physical, chemical and biological functions and also a key indicator of soil quality (Murphy, 2015). SOM is both a source and sink of organic forms of carbon $(\mathrm{C})$, nitrogen $(\mathrm{N})$, phosphorus $(\mathrm{P})$, and sulphur (S) (Kirkby et al., 2011; Murphy, 2015). In the organic farming, decomposition of soil organic matter (SOM) through the activities of soil microorganism releases essential nutrients and make them available for plant growth. Hence, organic farming systems are known to improve both chemical and biological soil quality and subsequently increases the crop yield (Fließbach et al., 2007). Soil biochemical activities of microorganisms play an essential role in nutrient mineralization and the decomposition of organic matter and are key drivers of nutrient supply to plants. Soil enzyme activities give information about soil microbial and physicochemical status, act as "sensors" of soil organic matter (SOM) decomposition (Aon and Colaneri, 2001; Baum et al., 2003; Sinsabaugh et al., 2008).
Further, these have been used to elucidate influence of soil treatments on soil fertility (Chen et al., 2003), and correlate well with nutrient availability (Asmar et al., 1994; János et al., 2011). Moreover, they respond quickly to physical and chemical changes in soil, including nutrient availability (Anderson et al., 2002; Giacometti et al., 2013). Conversely, loss of any microbial biochemical activity is an indicator of decreased soil quality (Chapman et al., 2007; Chiurazzi, 2008; Zak et al., 1994). Application of Organic amendment increases overall enzyme activity (Mäder et al., 2002; García-Ruiz et al., 2008; Moeskops et al., 2010). However, activities of specific enzymes are influenced by several factors; composition of the amendments and its $\mathrm{pH}$, texture and relative availability of nutrients (Acosta-Martínez et al., 2007; Sinsabaugh et al., 2008; Stursová and Baldrian, 2010). Higher enzyme activities were reported in the rhizosphere than in bulk soil. The probable reason is greater microbial activities on rhizosphere, sustained by root exudates and enzymes (George et al., 2005; Villányi et al., 2006. For long term agricultural sustainability microbial biomass acts as a reservoir of nutrients (Melero et al., 2006).

\section{Materials and Methods}

\section{Experimental site}

To investigate the effect of organic amendments ( $S$. rostrata)) over conventional fertilization (inorganic fertilizers) on microbial population, soil microbial enzyme activity and crop yield, a field experiment was conducted in a $402 \mathrm{~m}^{2}$ plot at Norman-E-Borlaug crop Research Center (NBRC) of G.B. Pant University of Agriculture and Technology, Pantnagar, Uttarakhand, located at altitude of $29^{\circ} \mathrm{N}$, longitude $79^{\circ} \mathrm{E}$ and an elevation of $243.8 \mathrm{~m}$ above sea level. 


\section{Field trial and agronomical parameters}

For the analysis of effect of organic treatment on crop yield, field experiment was conducted in a $402 \mathrm{~m}^{2}$ plot at Norman-E-Borlaug crop Research Center (NBRC) of G.B. Pant University of Agriculture and Technology, Pantnagar, Uttarakhand. The soil of experimental plot was silt clay loam in texture and belongs to the order mollisol (USDA classification). The climatic conditions of experimental site vary from subtropical to temperate, with annual rainfall of 1000-2000 $\mathrm{mm}$ and temperature variation from $8{ }^{\circ} \mathrm{C}-46^{\circ} \mathrm{C}$ during winters and summer respectively. The experiment was set in randomized completeblock design. Experimental plots were cultivated with rice var Pusa Basmati I amended with green manure and inorganic fertilizers for organic and conventional treatments respectively. The agronomical parameters such as root length, root dry weight, plant height, and number of productive tillers were studied. Results were statistically analysed by two factorial analysis of variance (ANOVA2). Significance between treatments determined at $\mathrm{p}$ value $<0.05$.

\section{Sampling and soil analysis}

Soil was sampled from two depths of $0-15$ and $15-30 \mathrm{~cm}$ during various time intervals of growth (before ploughing, after transplantation (0 DAT), maximum tillering (45 DAT), flowering (60DAT) and maturity period (90 DAT). Moist field soil was sieved and divided into two subsamples. One was immediately stored at $4{ }^{\circ} \mathrm{C}$ in sampling bags loosely tied to ensure sufficient aeration until assaying of microbiological and enzymatic activities. The other was air-dried for physicochemical analysis.

\section{Soil physico-chemical properties}

All soil samples were analyzed for $\mathrm{pH}$, oxidizable organic carbon, available phosphate, available potassium, ammonical nitrogen and nitrate nitrogen using soil testing kit from HiMedia laboratories.

\section{Total bacterial count}

The total aerobic bacterial count was enumerated through serial dilution spread plating on Nutrient agar media and incubated at $28 \pm 1^{\circ} \mathrm{C}$ for $2-3$ days in BOD. The bacterial colonies were enumerated and expressed as $\log \mathrm{cfu} \mathrm{g}^{-1}$ of soil.

\section{Determination of soil enzyme activities}

Organic amendment leads to changes in the functioning of the system, as evaluated by soil enzyme activities. The soil health was monitored by estimating activities of four soil enzymes, dehydrogenase, fluorescein diacetate, alkaline phosphatase and urease in soil samples at different crop growth stages from soil depth $(0-15 \mathrm{~cm})$. The hydrolysed product of each enzyme was analysed spectrophotometrically and compared with a standard curve. All assays were conducted in triplicates. Urease activity was determined as given by Kandeler and Gerber (1988). Five grams of field moist soil was placed in 50-ml Erlenmeyer flasks drenched with $2.5 \mathrm{ml} 0.08$ $\mathrm{M}$ urea solution and incubated at $37^{\circ} \mathrm{C}$. After $2 \mathrm{~h}$ incubation $50 \mathrm{ml}$ of $1 \mathrm{~N} \mathrm{KC1}$ was added and shaken for $30 \mathrm{~min}$. The resulting suspensions were filtered. One $\mathrm{ml}$ of filtrate was diluted to $10 \mathrm{ml}$ with DW followed by addition of $5 \mathrm{ml}$ Sodium salicylate and $2 \mathrm{ml}$ $0.1 \%$ sodium dichlorisocyanurate. The samples were incubated at $28 \pm 1^{\circ} \mathrm{C}$ for $30 \mathrm{~min}$ and absorbance read at $690 \mathrm{~nm}$.

Alkaline phosphomonoesterases activity was analysed according to a method of Tabatabai and Bremner (1969). $1 \mathrm{gm}$ of moist soil was placed in a 50-ml Erlenmeyer flask, $4 \mathrm{ml}$ of Modified Universal Buffer (MUB), $0.25 \mathrm{ml}$ of toluene; $1 \mathrm{ml}$ of p-nitrophenyl phosphate (PNPP) solution was added and swirled for a 
few seconds to mix the contents and flasks incubated at $37^{\circ} \mathrm{C}$. After $1 \mathrm{~h}, 1 \mathrm{ml}$ of $0.5 \mathrm{M}$ calcium chloride and $4 \mathrm{ml}$ of $0.5 \mathrm{M}$ sodium hydroxide was added. Thoroughly mixed soil suspension was filtered and analyzed spectrophotometrically at $400 \mathrm{~nm}$.

Fluorescein diacetate hydrolyses was determined according to the method of Inbar et al., (1991). 1 gm of field moist soil taken in Erlenmeyer flask was drenched with $1 \mathrm{ml}$ of FDA solution and $15 \mathrm{ml}$ of buffer. The flasks were shaken for 20 min on a rotary shaker at $25^{\circ} \mathrm{C}$, after which $10 \mathrm{ml}$ of acetone was added for extraction. The samples were filtered and absorbance measured at $490 \mathrm{~nm}$. Dehydrogenase enzyme activity was estimated according to the method of Thalmann (1968). $5 \mathrm{gm}$ field moist soil was placed in Erlenmeyer flask and $5 \mathrm{ml}$ TTC-TRIS buffer was added followed by $24 \mathrm{~h}$ incubation at $30^{\circ} \mathrm{C}$ in the dark. Thereafter, the sample was extracted with $25 \mathrm{ml}$ acetone. The resulting solution was shaken for $2 \mathrm{~h}$ in the dark and filtered. The absorbance of the triphenylformazen formed was measured immediately at $546 \mathrm{~nm}$ on PE Lambda 35 spectrophotometer.

\section{Results and Discussion}

\section{Soil physico - chemical properties}

The soil was sampled from organic and conventional plots after the harvesting of previous crop as well as after the transplantation of rice variety Pusa basmati I and assayed for its physico-chemical properties $(\mathrm{pH}$, organic carbon, ammonical nitrogen, nitrate nitrogen, available form of phosphate (AP) and potassium (AK). The initial $\mathrm{pH}$ of soil was calculated as 8.0-8.5. The $\mathrm{pH}$ gradually decreased upto 7.5 in organic treatment whereas increases for conventional treatment and is measured as 8.5 at crop maturity (Table 1). Alkaline $\mathrm{pH}$ of the soil before the application of organic amendment might be explained by the fact that the residues of previous crop and chemical fertilizers tend to make the soil alkaline (Massey et al., 2009). However, the decrease in $\mathrm{pH}$ reaching near neutral with organic treatment may be due to the green manure itself or by the high microbial count (as $\mathrm{cfu} \mathrm{g}^{-1}$ and their metabolic activities as represented by soil enzyme activities. Dumbrell et al., (2010) reported that bacterial diversity varies with Soil $\mathrm{pH}$ and was highest in neutral soil. Total organic carbon status is an indicator of soil fertility. In soil its status changes quickly due to application of either chemical, biological or pesticides. In present study total organic carbon increased from initial concentration $\left(\mathrm{kgha}^{-1}\right) 0.300$ to 0.750 at crop maturity (90DAT) in organic treatment and $0.100-0.500 \mathrm{kgha}^{-1}$ in conventional fertilized soil. Other parameters like available phosphate, available potassium, and ammonical nitrogen were not significantly affected with organic or inorganic treatments (Table 1). There was no significant increase or decrease in their concentration with respect to the growth period of the plants as shown in Table 2. Whereas, nitrate nitrogen concentration increased in organic treatment. It increased from $4 \mathrm{kgha}^{-1}$ before ploughing to $10 \mathrm{kgha}^{-1}$ at maturity stage (90DAT).

\section{Total bacterial count}

In field amended with green manure bacterial population increased from 6.62 to $6.80 \log$ cfu $\mathrm{g}^{-1}$ during different growth stages of crop whereas, from 6.57 to $6.72 \log \mathrm{cfu} \mathrm{g}^{-1}$ in field applied with inorganic fertilizer (Fig. 2). Similar observations were reported in previous studies. Organic amendment improves soil microflora and structure (Crecchio et al., 2001). Birkhofer et al., (2008) observed a similar increase in microbial biomass and activity in organically treated compared with conventional. 
Table.1 Total bacterial count and soil physicochemical properties in organic and conventional treatments at different crop growth stages

\begin{tabular}{|c|c|c|c|c|c|c|c|c|}
\hline Treatment & Sampling time & Log cfu/g-1 soil & Soil pH & $\begin{array}{l}\text { Organic Carbon } \\
\left(\mathrm{Kg} / \mathrm{ha}^{-1}\right)\end{array}$ & $\begin{array}{l}\text { Available } \\
\text { phosphorous } \\
\left(\mathrm{Kg} / \mathrm{ha}^{-1}\right)\end{array}$ & $\begin{array}{l}\text { Available } \\
\text { potassium } \\
\left(\mathrm{Kg} / \mathrm{ha}^{-1}\right)\end{array}$ & $\begin{array}{l}\text { Ammonical } \\
\text { nitrogen } \\
\left(\mathrm{Kg} / \mathrm{ha}^{-1}\right)\end{array}$ & $\begin{array}{l}\text { Nitrate } \\
\text { nitrogen } \\
\left(\mathrm{Kg} / \mathrm{ha}^{-1}\right)\end{array}$ \\
\hline control & Before ploughing & 6.62 & $8.0-8.5$ & $\operatorname{ML}(0.300-0.500)$ & $\mathrm{L}(<22)$ & $\mathrm{M}(112-280)$ & $\mathrm{L}(15)$ & VL(4) \\
\hline Organic & After & 6.65 & $8.5-9.0$ & $\operatorname{ML}(0.300-0.500)$ & $M(22-56)$ & $\mathrm{M}(112-280)$ & $\mathrm{L}(15)$ & VL(4) \\
\hline Conventional & transplantation & 6.57 & 8.5 & $\operatorname{ML}(0.300-0.500)$ & $M(22-56)$ & $\mathrm{L}(<112)$ & $\mathrm{M}(73)$ & VL(4) \\
\hline Organic & 45 days & 6.67 & 8.5 & $\operatorname{ML}(0.300-0.500)$ & $\mathrm{L}(<22)$ & $\mathrm{M}(112-280)$ & $\mathrm{L}(15)$ & $\mathrm{M}(20)$ \\
\hline Conventional & & 6.65 & 9.0 & $\operatorname{ML}(0.300-0.500)$ & $\mathrm{L}(<22)$ & H(280-392) & $\mathrm{M}(73)$ & VL(4) \\
\hline Organic & 60 days & 6.72 & $7.5-8.5$ & $\mathrm{M}(0.500-0.750)$ & $\mathrm{L}(<22)$ & $\mathrm{M}(112-280)$ & $\mathrm{L}(15)$ & VL(4) \\
\hline Conventional & & 6.67 & $9.0-9.5$ & $\operatorname{ML}(0.300-0.500)$ & $\mathrm{MH}(56-73)$ & $\mathrm{M}(112-280)$ & $\mathrm{M}(73)$ & VL(4) \\
\hline Organic & 90 days & 6.80 & $7.0-7.5$ & $\mathrm{M}(0.500-0.750)$ & $\mathrm{L}(<22)$ & $\mathrm{M}(112-280)$ & $\mathrm{L}(15)$ & $\mathrm{L}(10)$ \\
\hline Conventional & & 6.72 & $8.5-9.0$ & $\operatorname{ML}(0.300-0.500)$ & $\mathrm{H}(>73)$ & $\mathrm{M}(112-280)$ & $\mathrm{L}(15)$ & $\mathrm{L}(10)$ \\
\hline
\end{tabular}

$\mathrm{M}=$ Medium, $\mathrm{ML}=$ Medium Low, $\mathrm{L}=$ Low, $\mathrm{H}=$ High

Table.2 Soil enzyme activities in organic and conventional treatments days after transplantation

\begin{tabular}{|c|c|c|c|c|c|c|c|c|c|c|c|c|}
\hline $\begin{array}{l}\text { Treatmen } \\
\text { ts }\end{array}$ & \multicolumn{3}{|c|}{$\begin{array}{l}\text { Dehydrogenase activity } \\
\left(\mu \mathrm{gTPFg}^{-1} \mathrm{Soil} / 24 \mathrm{~h}^{-1}\right)\end{array}$} & \multicolumn{3}{|c|}{ FDA ( $\mu$ g hydrolyzed FDA/g $\mathrm{g}^{-1}$ soil) } & \multicolumn{3}{|c|}{$\begin{array}{l}\text { Alkaline phosphatase } \\
\left(\mu \mathrm{PPNPg}^{-1} \mathrm{soil}^{-1} \mathrm{~h}^{-1}\right)\end{array}$} & \multicolumn{3}{|c|}{ Urease $\left(\mu \mathrm{gNH}_{4}^{+} \mathrm{g}^{-1} \mathrm{soil}^{-\mathrm{h}^{-1}}\right)$} \\
\hline & 45DAT & 60DAT & 90DAT & 45DAT & 60DAT & 90DAT & 45DAT & 60DAT & 90DAT & 45DAT & 60DAT & 90DAT \\
\hline$\overline{\mathbf{O}}$ & $62.22 \pm 1.4$ & $67.77 \pm 1.4$ & $93.33 \pm 1.9$ & $102.11 \pm 0.09$ & $103.09 \pm 0.19$ & $113.75 \pm 1.5$ & $31.96 \pm 0.19$ & $36.79 \pm 0.76$ & $35.91 \pm 0.16$ & $14.16 \pm 0.34$ & $27.08 \pm 1.04$ & $30.58 \pm 0.55$ \\
\hline $\mathbf{C}$ & $60.00 \pm 0.9$ & $61.66 \pm 1.6$ & $80.55 \pm 1.1$ & $90.41 \pm 0.15$ & $91.25 \pm 0.31$ & $96.38 \pm 0.5$ & $31.71 \pm 0.11$ & $38.69 \pm 0.32$ & $39.75 \pm 0.29$ & $11.96 \pm 0.10$ & $23.28 \pm 0.21$ & $27.30 \pm 0.14$ \\
\hline
\end{tabular}




\section{Soil enzyme activities}

Several previous studies reported that organic management increases overall enzyme activity (Mäder et al., 2002; García-Ruiz et al., 2008; Moeskops et al., 2010). At the beginning of experiment different soil microbial enzyme activities were calculated as 61.66 and $60.00 \mu \mathrm{g}$ (TPF g $\mathrm{g}^{-1} / 24 \mathrm{~h}^{-1}$ ) for dehydrogenase, 99.61 .04 and $89.47 \mu \mathrm{g}$ (FDA $\left.\mathrm{g}^{-1} / \mathrm{h}^{-1}\right)$ fluorescein diacetate, 31.37 and 31.18 ( $\mathrm{PNP} \mathrm{g}^{-1} / \mathrm{h}^{-1}$ ) alkaline phosphatase, and 6.61 and $6.25 \mu \mathrm{g}\left(\mathrm{NH}_{4}{ }^{+} \mathrm{g}^{-1} / \mathrm{h}^{-1}\right)$ for urease in organic and conventional treatments respectively (Table 2). However at crop maturity (90 DAT), the increase in enzyme activity by 93.33 and $80.55 \mu \mathrm{g}$ (TPF $\mathrm{g}^{-1 / 24}$ $\left.\mathrm{h}^{-1}\right), 113.75$ and $96.38 \mu \mathrm{g}\left(\right.$ FDA g $\left.^{-1} / \mathrm{h}^{-1}\right)$ (Fig. 1), 35.91 and $39.75\left(\mathrm{PNP} \mathrm{g}^{-1 /} \mathrm{h}^{-1}\right)$ and 30.58 and $27.30 \mu \mathrm{g}\left(\mathrm{NH}_{4}{ }^{+} \mathrm{g}^{-1} / \mathrm{h}^{-1}\right)$ for organic and conventional treatments respectively (Fig. 1). Results were statistically analysed and found significant at $\mathrm{p}<0.05$. It was observed that treatment with green manure ( $S$. rostrata) enhanced the enzyme activity more than inorganic fertilizer application. Initially the increase was gradual but after 60 DAT drastic increase was observed for dehydrogenase, urease and fluorescein diacetate. However, alkaline phosphatase activity decreased in green manure amended field. The probable reason could be decrease in $\mathrm{pH}$ during various crop growth stages. Soil $\mathrm{pH}$ influences its microbial activity. This indicates that active microbial population in soil plays important role in all enzyme activities (Tabatabai, 1994; Burns et al., 2013). They depolymerize the structurally diverse polymeric macromolecules, which is the rate-limiting step in decomposition and nutrient mineralization potential of soil (Schimel and Bennett, 2004). However at crop maturity the activities of all soil enzymes showed an increasing trend. The organic amendment with $S$. rostrata positively contributed to the increase in overall bacterial population and hence increased soil microbial enzyme activities.

\section{Agronomical parameters and crop yield}

Agronomical parameters (plant height, root length, dry weight and number of tillers) were studied for the rice plant grown under organic and conventional treatments and the results were compared. All the studied agronomic parameters positively correlated with organic treatment but crop yield was lower in organically amended field. The yield in organic amended and conventionally fertilized soil was 39.14 and $41.81 \mathrm{q} / \mathrm{ha}^{-1}$ respectively (Fig. 3).

Present study investigated the effects of green manure (organic amendment) on soil quality as determined by soil physico- chemical properties by microbial population in soil. There was not much difference in soil physicochemical properties of organically and conventionally amended field. Therefore, soil physicochemical properties alone were not sensitive enough to track relatively subtle soil quality improvements in short term organic treatments over conventional one. Similar conclusions were drawn by (Mijangos et al., 2006 and Parr and Papendick (1997) who reported that physical and chemical properties of soil usually change very slowly and at a temporal scale which is not supposed to be suitable for short-term management practices (Roberto Garc1'a-Ruiz et al., 2008). Our study demonstrated that experimental site supplemented with green manure exhibited greater biological activity (i.e. soil enzymes activities) than the conventional amendment and similar observations have been preiously reported by (Mader et al., (2002), van Diepeningen et al., (2006), Melero et al., (2006) and Benitez et al., (2006). Dehydrogenase, as an indicator of oxidoreductase activity of soil micro- biota (Alef and Nannipieri, 1995), was found 
higher in organically managed soil. Similar results were obtained with FDA and urease which participate in esterase activity and nitrogen cycle respectively. These results are supported by Gupta and Germida (1988), Bandick and Dick (1999), Riffaldi et al., (2002), and Sena et al., (2002) under organic practices. The soil enzyme activities were due to biochemical activities of microorganism present in soil. Thus, soil microbial population is directly correlated with soil enzyme activities. Several studies have reported that microbial populations in soil are $\mathrm{pH}$ sensitive higher populations are reported at neutral $\mathrm{pH}(\mathrm{pH}$ 6-7). In present study highest bacterial population was reported in organic amendment at $\mathrm{pH} 7.6$, slightly higher than neutral limit. However, yield was significantly higher in conventional 41.81 $\mathrm{q} / \mathrm{ha}^{-1}$ as compared to organic amended 39.14 $\mathrm{q} / \mathrm{ha}^{-1}$. It has been reported that organic manuring takes at least 3-5 years to become fully effective. Although initial yield is comparatively less in organic treatment but will increase gradually over the years. From present study we found that bacterial populations and their biochemical activities (enzyme analysis) in soil are major determinant of soil fertility in short term organic practices. Thus, organic farming is an eco-friendly approach that protects soil from detrimental effect of inorganic fertilizers and maintain soil fertility as a result crop yield increases.

Use of organic amendment significantly increased soil microbial biomass and enzyme activities during complete crop cycle from transplantation to crop maturity. It is obvious that application of organic manure increases the nutrient availability as a result microbial population and soil enzyme activities increases simultaneously. However, they may be very sensitive early indicators of soil quality. It can be concluded that use of organic manure for fertilization management can be recommended as a means for promoting soil fertility and productivity.

\section{Acknowledgement}

Research facilities including field provided by Director Experiment Station G.B. Pant University Agriculture and Technology Pantnagar, Uttarakhand are dully acknowledged.

\section{References}

Acosta-Martinez, V., Cruz, L., SotomayorRamirez, D., and Pérez-Alegría, L. 2007. Enzyme activities as affected by soil properties and land use in a tropical watershed. Appl. Soil. Ecol. 35(1): 3545.

Alef, K., and Nannipieri, P. (Eds.) 1995. Methods in Applied Soil Microbiology and Biochemistry, Academic Press, London.

Anderson, S. P., Dietrich, W. E., and Brimhall, Jr. G. H. 2002. Weathering profiles, mass-balance analysis, and rates of solute loss: Linkages between weathering and erosion in a small, steep catchment. Geol. Soc. Am. Bull. 114(9): 1143-1158.

Anonymous, 2012. India.gov.in/sectors/ agriculture/area production yield/rice.

Aon, M. A., and Colaneri, A. C. 2001. II. Temporal and spatial evolution of enzymatic activities and physicochemical properties in an agricultural soil. Appl. Soil. Ecol. 18(3): 255-270.

Asmar, F., Eiland, F., and Nielsen, N. E. 1994. Effect of extracellular-enzyme activities on solubilization rate of soil organic nitrogen. Biol. Fertil. Soils. 17(1): 32-38.

Bandick, A. K., and Dick, R. P. 1999. Field management effects on soil enzyme activities. Soil. Biol. Biochem. 31 (11): 1471-1479. 
Baum, C., Leinweber, P., and Schlichting, A. 2003. Effects of chemical conditions in re-wetted peats on temporal variation in microbial biomass and acid phosphatase activity within the growing season. Appl. Soil. Ecol. 22 (2): 167-174.

Benitez, E., Nogales, R., Campos, M., and Ruano, F., 2006. Biochemical variability of olive-orchard soils under different management systems. Appl. Soil. Ecol. 32 (2): 221-231.

Birkhofer, K., Bezemer, T. M., Bloem, J., Bonkowski, M., Christensen, S., Dubois, D., and Mäder, P. 2008. Longterm organic farming fosters below and aboveground biota: implications for soil quality, biological control and productivity. Soil Biol. Biochem., 40 (9): 2297-2308.

Burns, R. G., DeForest, J. L., Marxsen, J., Sinsabaugh, R. L., Stromberger, M. E., Wallenstein, M. D., and Zoppini, A., 2013. Soil enzymes in a changing environment: current knowledge and future directions. Soil. Biol. Biochem. 58: 216-234.

Chen, J. H. 2003. The combined use of chemical and organic fertilizers and/or biofertilizer for crop growth and soil fertility. In International workshop on sustained management of the soilrhizosphere system for efficient crop production and fertilizer use 16: 20. Land Development Department Bangkok, Thailand.

Chiurazzi, M. 2008. Microbial diversity as soil quality indicator in agricultural soils (Doctoral dissertation, Università degli Studi di Napoli Federico II).

Crecchio, C., Curci, M., Mininni, R., Ricciuti, P., and Ruggiero, P. 2001. Short-term effects of municipal solid waste compost amendments on soil carbon and nitrogen content, some enzyme activities and genetic diversity. Biol. Fertil. Soils. 34 (5): 311-318.
DAC, FW A. S. C. I and NSDC M. eBulletin.

Dumbrell, A. J., Nelson, M., Helgason, T., Dytham, C., and Fitter, A.H. 2010. Relative roles of niche and neutral processes in structuring a soil microbial community. ISME. J. 4 (3): 337.

Fließbach, A., Oberholzer, H. R., Gunst, L., and Mäder, P. 2007. Soil organic matter and biological soil quality indicators after 21 years of organic and conventional farming. Agric. Ecosyst. Environ.118 (1-4): 273-284.

García-Ruiz, R., Ochoa, V., Hinojosa, M. B., and Carreira, J. A. 2008. Suitability of enzyme activities for the monitoring of soil quality improvement in organic agricultural systems. Soil. Biol. Biochem. 40 (9): 2137-2145.

George, T. S., Turner, B. L., Gregory, P. J., Cade- Menun, B. J., and Richardson, A. E. 2005. Depletion of organic phosphorus from Oxisols in relation to phosphatase activities in the rhizosphere. Eur. J. Soil. Sci. 57 (1): $47-$ 57.

Giacometti, C., Cavani, L., Baldoni, G., Ciavatta, C., Marzadori, C., and Kandeler, E. 2013. Microplate-scale fluorometric soil enzyme assays as tools to assess soil quality in a long-term agricultural field experiment. Appl. Soil Ecol., 75: 80-85.

Gupta, V. V. S. R., and Germida, J. J. 1988. Distribution of microbial biomass and its activity in different soil aggregate size classes as affected by cultivation. Soil. Biol. Biochem. 20(6): 777-786.

Inbar, Y., Boehm, M. J., and Hoitink, H. A., 1991. Hydrolysis of fluorescein diacetate in sphagnum peat container media for predicting suppressiveness to damping-off caused by Pythium ultimum. Soil. Biol. Biochem. 23(5): 479-483. 
János, I., Szathmáry, L., Nadas, E., Beni, A., Dinya, Z., and Mathe, E. 2011. Evaluation of elemental status of ancient human bone samples from Northeastern Hungary dated to the 10th century AD by XRF. Nuclear Instruments and Methods in Physics Research Section B: Beam Interactions with Materials and Atoms 269 (21): 2593-2599.

Kandeler, E., and Gerber, H. 1988. Short-term assay of soil urease activity using colorimetric determination of ammonium. Biol. Fertil. Soils. 6 (1): 6872.

Kirkby, C. A., Kirkegaard, J. A., Richardson, A. E., Wade, L. J., Blanchard C and Batten G 2011. Stable soil organic matter: a comparison of $\mathrm{C}$ : $\mathrm{N}$ : $\mathrm{P}: \mathrm{S}$ ratios in Australian and other world soils. Geoderma 163(3-4): 197-208.

Kontopoulou, C. K., Bilalis, D., Pappa, V. A., Rees, R. M., and Savvas, D. 2015. Effects of organic farming practices and salinity on yield and greenhouse gas emissions from a common bean crop. Sci. Hortic. 183: 48-57.

Lernoud, J., Willer, H., and Kilcher, L. 2016. The World of Organic Agriculture. Statistics and Emerging Trends.

Mäder, P., Fliessbach, A., Dubois, D., Gunst, L., Fried, P., and Niggli, U. 2002. Soil fertility and biodiversity in organic farming. Science. 296 (5573): 16941697.

Massey, M. S., Davis, J. G., Ippolito, J. A., and Sheffield, R. E. 2009. Effectiveness of recovered magnesium phosphates as fertilizers in neutral and slightly alkaline soils. Agron. J. 101(2): 323329.

Melero, S., Porras, J. C. R., Herencia, J. F., and Madejon, E. 2006. Chemical and biochemical properties in a silty loam soil under conventional and organic management. Soil Tillage Res. 90 (1-2): 162-170.

Mijangos, I., Pérez, R., Albizu, I., and Garbisu, C. 2006. Effects of fertilization and tillage on soil biological parameters. Enzyme Microb. Technol. 40 (1): 100-106.

Moeskops, B., Buchan, D., Sleutel, S., Herawaty, L., Husen, E., Saraswati, R., and De Neve, S. (2010). Soil microbial communities and activities under intensive organic and conventional vegetable farming in West Java, Indonesia. Appl. Soil Ecol. 45 (2): 112120.

Murphy, C. J., Baggs, E. M., Morley, N., Wall, D. P., and Paterson, E. 2015. Rhizosphere priming can promote mobilisation of N-rich compounds from soil organic matter. Soil Biol. Biochem. 81: 236-243.

Parr, J. F., and Papendick, R. I., 1997. Soil quality: relationships and strategies for sustainable dryland farming systems. Annals of Arid Zone. 36 (3): 181-191.

Riffaldi, R., Saviozzi, A., Levi-Minzi, R., and Cardelli, R. 2002. Biochemical properties of a Mediterranean soil as affected by long-term crop management systems. Soil Tillage Res. 67 (1): 109114.

Schimel, J. P., and Bennett, J. 2004. Nitrogen mineralization: challenges of a changing paradigm. Ecology 85(3): 591-602.

Sena, M. M., Frighetto, R.T.S., Valarini, P. J., Tokeshi, H., and Poppi, R. J. 2002. Discrimination of management effects on soil parameters by using principal component analysis: a multivariate study. Soil Tillage Res. 67 (2): 171-181.

Sinsabaugh, R. L., Lauber, C. L., Weintraub, M. N., Ahmed, B., Allison, S. D., Crenshaw, C., and Gartner T B 2008. Stoichiometry of soil enzyme activity at global scale. Ecol. Lett. 11(11): 12521264. 
Štursová, M., and Baldrian, P. 2010. Effects of soil properties and management on the activity of soil organic matter transforming enzymes and the quantification of soil-bound and free activity. Plant soil. 338 (1-2): 99-110.

Tabatabai, M.A. 1994. Soil enzymes. Encyclopedia of Environmental Microbiology.

Tabatabai, M. A., and Bremner, J. M. 1969. Use of p-nitrophenyl phosphate for assay of soil phosphatase activity. Soil Biol. Biochem. 1 (4): 301-307.

Thalmann, A. 1968. Zur Methodik der Bestimmung der Dehydrogenase aktivit At im Boden mittels triphenyl tetrazoliumchlorid (TTC). Landwirtsch Forsch, 21: 249-258.

Van Diepeningen, A. D., de Vos, O. J., Korthals $\mathrm{G}$ W and van Bruggen $\mathrm{A} \mathrm{H}$
2006. Effects of organic versus conventional management on chemical and biological parameters in agricultural soils. Appl. Soil Ecol. 31 (1-2): 120135.

Villányi, I., Füzy, A., Angerer, I., and Biró, B., 2006. Total catabolic enzyme activity of microbial communities. Fluorescein diacetate analysis (FDA). Understanding and modelling plant-soil interactions in the rhizosphere environment. Handbook of methods used in rhizosphere research. 441-442.

Zak, J. C., Willig, M. R., Moorhead, D. L., and Wildman, H. G.1994. Functional diversity of microbial communities: a quantitative approach. Soil Biol. Biochem. 26 (9): 1101-1108.

\section{How to cite this article:}

Vandana Jaggi, Samiksha Joshi, Hemant Dasila, B.S. Mahapatra and Manvika Sahgal. 2018. Evaluation of Soil Health in Short Term Organic Vs Conventional Practices during Paddy Cultivation. Int.J.Curr.Microbiol.App.Sci. 7(04): 495-504. doi: https://doi.org/10.20546/ijcmas.2018.704.058 